\title{
Application of a Kinetic Model for Analysis of Salt Absorption of Crop Roots under the Salinized Condition
}

\author{
Ryosuke NomiYAmA ${ }^{1}$, Yuki SAGO ${ }^{1,2}$, Daisuke YASUTAKE $^{3}$ and Masaharu KITANO \\ ${ }^{\prime}$ Faculty of Agriculture, Kyushu University, Fukuoka, 812-8581 Japan \\ ${ }^{2}$ Department of Environmental and Life Science Engineering, Toyohashi \\ University of Technology, Toyohashi, Aichi, 441-8580 Japan \\ ${ }^{3}$ Faculty of Agriculture, Kochi University, Nankoku, Kochi, 783-8502 Japan
}

(Received March 26, 2012; Accepted May 11, 2012)

\begin{abstract}
Salinization of crop fields under desertification closely relates to root absorptive functions of the major crops such as corn and sunflower plants. The rate of root salt absorption of corn and sunflower plants under the salinized condition were analyzed by applying the transpirationintegrated model of root ion absorption affected by leaf transpiration. The characteristics of root salt absorption were represented by two model parameters of $Q_{\max }$ and $K_{\mathrm{M}}{ }^{\prime}$ which relate to the potential absorbing power and the ion affinity of transport proteins on root cell membranes, respectively. In particular, the model parameter of $Q_{\max }$ can be an explanatory parameter to represent the specificity of plant species and ion species in root ion absorption. Identification of $Q_{\max }$ involved in the transpiration-integrated model of root ion absorption can be effective for simulating salt accumulation in crop fields under desertification.
\end{abstract}

Keywords : Helianthus annuus, root ion absorption, salinization, transpiration-integrated model, Zea mays

\section{INTRODUCTION}

In crop fields of arid and semi-arid regions under desertification, salt accumulation in the soil and groundwater has been a serious problem for sustainable agriculture (Food and Agriculture Organization, 2002). The salt accumulation in the crop fields closely relates to root absorptive functions of the major crops such as corn plants (Kitano et al., 2006). Therefore, Yasutake et al. (2009a) measured root absorptive functions of the major crops such as corn and sunflower plants under the salinized condition using a nutrient film technique system and showed the specificity of plant species and ion species in root absorptive functions.

Root ion absorption is regulated through complicated processes with the active and selective ion uptake by ion-specific transport proteins on root cell membranes (Taiz and Zeiger, 2002), and many studies on root ion absorption have been carried out based on models involving ion transport across cell membranes. Ion absorption rate of roots depends on ion concentration around roots and can be represented by a concentration-dependent kinetic model on the basis of Michaelis-Menten equation (Epstein and Hagen, 1952; Sago et al., 2011a). Pitman (1977) proposed the root absorption model on the basis of the apoplastic and symplastic mechanism of ion transporting. Katou et al. (1986a, b) and Taura et al. (1988) regarded the apoplast as the ion transporting canal and pro-

Corresponding author: Masaharu Kitano, fax : +81-92-642-2923, e-mail : kitano@bpes.kyushu-u.ac.jp 


\section{R. NOMIYAMA ET AL.}

posed the canal model and the dual canal model, respectively. Those studies suggested that root ion absorption largely depends on the apoplastic water transport driven by root water absorption (i.e. leaf transpiration). Therefore, Sago et al. (2011b) modified the concentration-dependent model and developed a new model integrated with transpiration. In this study, water and salt absorption rates of corn and sunflower plants under the salinized condition measured by Yasutake et al. (2009a) were analyzed by applying the transpiration-integrated model newly developed by Sago et al. (2011b), and the model parameters were examined for quantitative representation of the specificity of plant species and ion species in root ion absorption.

\section{MATERIALS AND METHODS}

\section{NFT system}

Figure 1 shows a schematic diagram of the nutrient film technique (NFT) system developed for simultaneous evaluation of water and ion absorption by roots (Yasutake et al., 2004). The system consists of a circulation unit (NFT bed, reservoir tank, circulation path, etc.) and a solution supply unit (solution supply tank, solenoid valve, flow meter, supply path, etc.). The total volume of the nutrient solution in the circulation unit can be set by controlling the solution level in the reservoir tank: Corresponding to the solution loss with water absorption by roots, the solution was supplied from the supply tank, where the solution supply was manipulated by the on-off action of the solenoid valve on the supply path according to the signal from the water level sensor in the reservoir tank.

\section{Material plants and experimental conditions}

Corn (Zea mays L.) and sunflower plants (Helianthus annuus L.) were sown in plastic pots filled with vermiculite and were raised in a growth chamber for three weeks (Yasutake et al., 2009a). Thereafter, 80 plants of corn and sunflower were transplanted respectively on the two beds of the NFT system in a greenhouse (Nankoku, Kochi, Japan; $33^{\circ} 57^{\prime} \mathrm{N}, 133^{\circ} 68^{\prime} \mathrm{E}$ ) and were grown with the standard nutrient solution $\left(E C=1.0 \mathrm{dS} \mathrm{m}^{-1}\right)$ containing $\mathrm{Na}^{+}, 0.2 \mathrm{mmol} \mathrm{L}{ }^{-1} ; \mathrm{Cl}^{-}, 6.1 \mathrm{mmol}$

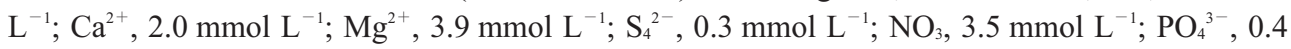
$\mathrm{mmol} \mathrm{L}{ }^{-1} ; \mathrm{K}^{+}, 2.2 \mathrm{mmol} \mathrm{L}^{-1}$. One week after transplanting, the standard nutrient solution was substituted for the salinized nutrient solution $\left(E C=5.0 \mathrm{dS} \mathrm{m}^{-1}\right)$ containing $\mathrm{Na}^{+}, 34.3 \mathrm{mmol} \mathrm{L}^{-1} ; \mathrm{Cl}^{-}$,

\section{CAPTIONS}

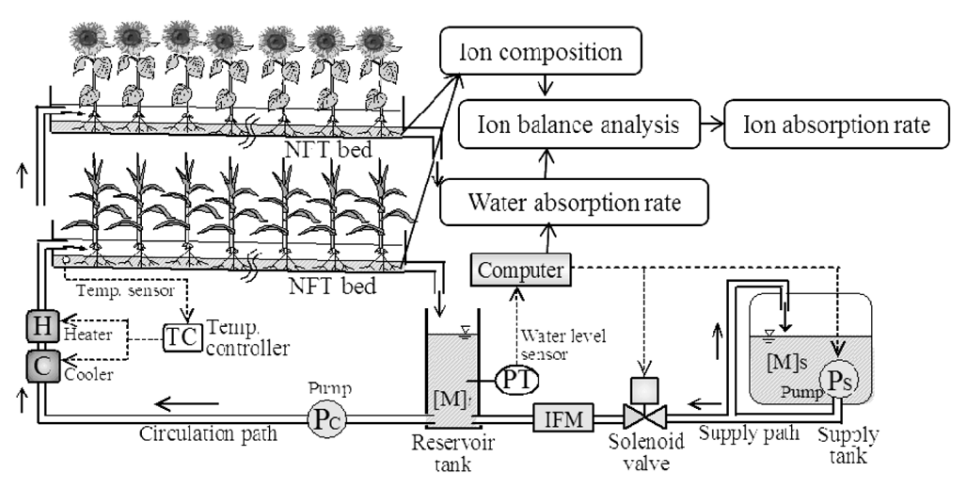

Fig. 1 Schematic diagram of the nutrient film technique (NFT) system developed for simultaneous evaluation of water and ion absorption by roots. The system consists of a circulation unit (NFT bed, reservoir tank, water pump, circulation path, etc.) and a solution supply unit (supply tank, solenoid valve, integrated flow meter, water pump, supply path, etc.). 
$45.2 \mathrm{mmol} \mathrm{L}{ }^{-1} ; \mathrm{Ca}^{2+}, 5.7 \mathrm{mmol} \mathrm{L}{ }^{-1} ; \mathrm{Mg}^{2+}, 11.9 \mathrm{mmol} \mathrm{L}{ }^{-1} ; \mathrm{SO}_{4}{ }^{2-}, 17.2 \mathrm{mmol} \mathrm{L}{ }^{-1} ; \mathrm{NO}_{3}, 2.9 \mathrm{mmol}$ $\mathrm{L}^{-1} ; \mathrm{PO}_{4}^{3-}, 0.2 \mathrm{mmol} \mathrm{L}{ }^{-1} ; \mathrm{K}^{+}, 1.3 \mathrm{mmol} \mathrm{L}{ }^{-1}$ : This solution was enriched especially with $\mathrm{Na}^{+}, \mathrm{Cl}^{-}$, $\mathrm{Ca}^{2+}$ and $\mathrm{Mg}^{2+}$ in order to imitate the salinized groundwater found in crop fields under desertification in the Yellow River basin (Yasutake et al., 2009b). The experiment was conducted for 31 days from July 31 to August 30, 2007, where the salinized nutrient solution of the circulation unit was renewed on August 9 and 19. The solution temperature of the circulation unit was controlled at $25^{\circ} \mathrm{C}$ using a heater, a cooler, and a temperature controller. Furthermore, solar radiation, air temperature, and relative humidity in the greenhouse were measured on-line.

Evaluation of water and ion absorption

The daily integrated rates of root water absorption (i.e. leaf transpiration) of corn and sunflower plant canopy growing in the respective beds were measured by the flow meter on the supply path at 1900 every evening. At the same time, $50 \mathrm{~mL}$ nutrient solution was sampled from each circulation unit, and the concentrations of $\mathrm{Na}^{+}, \mathrm{Cl}^{-}, \mathrm{Ca}^{2+}$ and $\mathrm{Mg}^{2+}$ in the solution samples were analyzed with an ion chromatograph system (ICS-90, DIONEX, Osaka, Japan); $\mathrm{Na}^{+}, \mathrm{Cl}^{-}, \mathrm{Ca}^{2+}$ and $\mathrm{Mg}^{2+}$ are the major ions which cause salinization of crop fields. The daily integrated rates of root ion absorption of corn and sunflower plant canopy growing in the respective beds were evaluated on the basis of ion balance analysis in the circulation unit by the method developed by Yasutake et al. (2004). Furthermore, water and ion absorption rates of the respective plant canopies were divided by the number of plants growing in the bed for evaluating the rates for a single plant. Both of water and ion absorption rates and ion concentration in root zone solution in corn and sunflower plants were not measured on August 9 and 19 because of the process for the regular renewal of the solution in the NFT bed. Furthermore, absorption rates in sunflower plants could not measured from August 14 to 16 because of a system trouble in the NFT system.

Kinetic models of root ion absorption

Root ion absorption depends on ion concentration in the root zone, and the concentrationdependent model of the root ion absorption can be expressed based on the Michaelis-Menten equation as (Epstein and Hagen, 1952; Sago et al., 2011a)

$$
Q_{\mathrm{M}}=Q_{\max } \frac{[\mathrm{M}]}{K_{\mathrm{M}}+[\mathrm{M}]}
$$

where $Q_{\mathrm{M}}\left(\mathrm{mmol} \mathrm{d}^{-1} /\right.$ plant) is the rate of ion $\mathrm{M}$ absorption by roots, $[\mathrm{M}]\left(\mathrm{mmol} \mathrm{L}^{-1}\right)$ is the concentration of ion $\mathrm{M}$ in the nutrient solution of the root zone, and $Q_{\max }\left(\mathrm{mmol} \mathrm{d}^{-1} / \mathrm{plant}\right)$ and $K_{\mathrm{M}}(\mathrm{mmol}$ $\mathrm{L}^{-1}$ ) are the parameters representing characteristics of root ion absorption. $Q_{\max }$ can be considered to indicate the potential ion absorbing power, while $K_{\mathrm{M}}$ can be considered to relate the affinity between ion $\mathrm{M}$ and the ion-specific transport protein under the lower concentrations of ion $\mathrm{M}$.

Furthermore, leaf transpiration $(T r)$ induces root water absorption and drives ion transport to root cell membranes by the mass flow, which can be considered to be responsible for the frequency of encounter between the respective ions and the ion-specific transport proteins on root cell membranes. The rate of ion transport to root cell membranes by this mass flow can be evaluated by $[\mathrm{M}] \cdot \operatorname{Tr}$. Therefore, Sago et al. (2011b) modified Eq. (1) and newly proposed the transpirationintegrated model of root ion absorption as

$$
Q_{\mathrm{M}}=Q_{\max } \frac{[\mathrm{M}] \cdot T r}{K_{\mathrm{M}}{ }^{\prime}+[\mathrm{M}] \cdot T r}
$$

where $\operatorname{Tr}\left(\mathrm{L} \mathrm{d}^{-1} /\right.$ plant) is the rate of leaf transpiration, and $K_{\mathrm{M}}{ }^{\prime}$ (mmol d ${ }^{-1} /$ plant) is the parameter which can be considered to reflect the affinity between the respective ions and the ion-specific transport proteins under the lower mass flow rates of $[\mathrm{M}] \cdot T r$. The transpiration-integrated model can evaluate root ion absorption rate affected by meteorological factors through changes in leaf transpiration and root water absorption. 
Figure 2 shows time courses of daily integrated solar radiation $\left(R_{\mathrm{S}}\right)$ in the greenhouse, daily integrated rate of transpiration $(T r)$ and leaf area $(L A)$ for a single plant of corn and sunflower growing under the salinized condition from July 30 to August 29,2007 . $R_{\mathrm{S}}$ fluctuated in a range between 2.2 and $13.6 \mathrm{MJ} \mathrm{m}^{-2} \mathrm{~d}^{-1}$ depending on weather conditions. The corn $L A$ increased to the maximum of $0.3 \mathrm{~m}^{2}$ /plant on 15 days after the start of the experiment and then decreased gradually. The sunflower $L A$ started to increase at a slow rate compared with the growth rate in the corn $L A$, but the sunflower $L A$ exceeded the corn $L A 25$ days after the start of the experiment and reached the maximum of $0.35 \mathrm{~m}^{2} /$ plant. $\operatorname{Tr}$ showed a trend to increase with growth of $L A$ and fluctuated depending on $R_{\mathrm{s}}$. Furthermore, throughout the experimental period, the sunflower $T r$ was approximately 1.5 times higher than the corn $T r$, while the sunflower $L A$ was approximately the same as the corn $L A$. This suggested that sunflower plants heve higher water absorbing power than corn plants.

Figure 3 shows time courses of daily integrated rates of root ion absorption $\left(Q_{\mathrm{Na}}, Q_{\mathrm{Cl}}, Q_{\mathrm{Ca}}\right.$ and $\left.Q_{\mathrm{Mg}}\right)$ and ion concentrations in the root zone solution $\left(\left[\mathrm{Na}^{+}\right],\left[\mathrm{Cl}^{-}\right],\left[\mathrm{Ca}^{2+}\right]\right.$ and $\left.\left[\mathrm{Mg}^{2+}\right]\right)$ for the respective ions of $\mathrm{Na}^{+}, \mathrm{Cl}^{-}, \mathrm{Ca}^{2+}$ and $\mathrm{Mg}^{2+}$ in corn and sunflower plants growing under the salinized condition. $\mathrm{Na}^{+}, \mathrm{Cl}^{-}, \mathrm{Ca}^{2+}$ and $\mathrm{Mg}^{2+}$ were highly concentrated in the root zone solution, and $\left[\mathrm{Na}^{+}\right]$, $\left[\mathrm{Cl}^{-}\right],\left[\mathrm{Ca}^{2+}\right]$ and $\left[\mathrm{Mg}^{2+}\right]$ showed a increasing trend during the respective intervals of the solution renewals. Root absorbing power for each of $\mathrm{Na}^{+}, \mathrm{Cl}^{-}, \mathrm{Ca}^{2+}$ and $\mathrm{Mg}^{2+}$ is low as compared with that for other ions such as the major essential nutrient ions of $\mathrm{NO}_{3}^{-}, \mathrm{PO}_{4}{ }^{3-}$ and $\mathrm{K}^{+}$, and this is considered to bring the salinization of the root zone solution with highly concentrated $\mathrm{Na}^{+}, \mathrm{Cl}^{-}, \mathrm{Ca}^{2+}$ and $\mathrm{Mg}^{2+}$. It was also found that the increasing $\left[\mathrm{Ca}^{2+}\right]$ was leveled off at a high concentration of about $20 \mathrm{mmol} \mathrm{L}^{-1}$. This can be considered to be brought by the solidification of $\mathrm{Ca}^{2+}$ at the excessively high $\left[\mathrm{Ca}^{2+}\right]$ in the salinized solution. Sunflower plants with the higher water absorbing power of roots and the higher $\operatorname{Tr}$ showed the higher $Q_{\mathrm{M}}$ for each of $\mathrm{Na}^{+}, \mathrm{Cl}^{-}, \mathrm{Ca}^{2+}$ and $\mathrm{Mg}^{2+}$ as

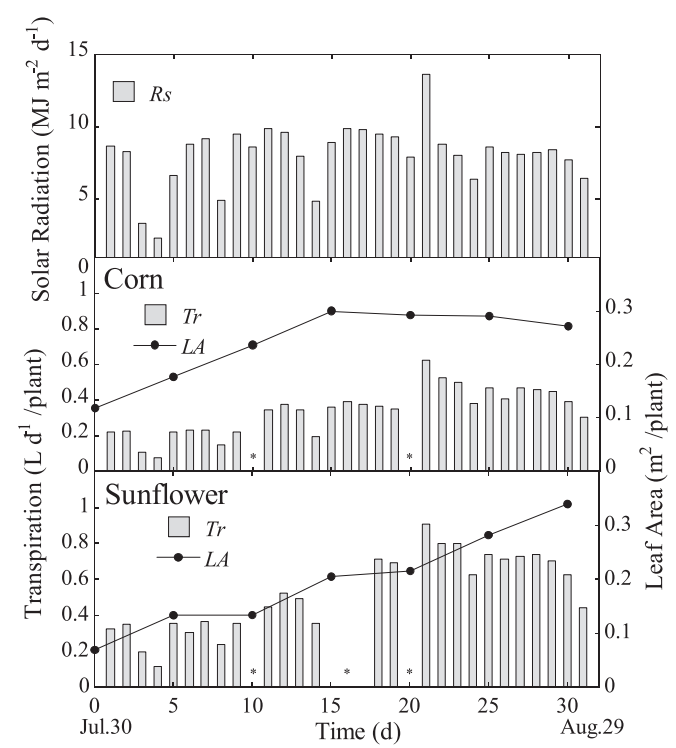

Fig. 2 Time courses of daily integrated solar radiation $\left(R_{\mathrm{S}}\right)$ in the greenhouse, daily integrated rate of transpiration $(T r)$ and leaf area $(L A)$ for a single plant of corn and sunflower growing under the salinized condition from July 30 to August 29, 2007 (*, not measured). 


\section{KINETIC MODEL OF ROOT SALT ABSORPTION}
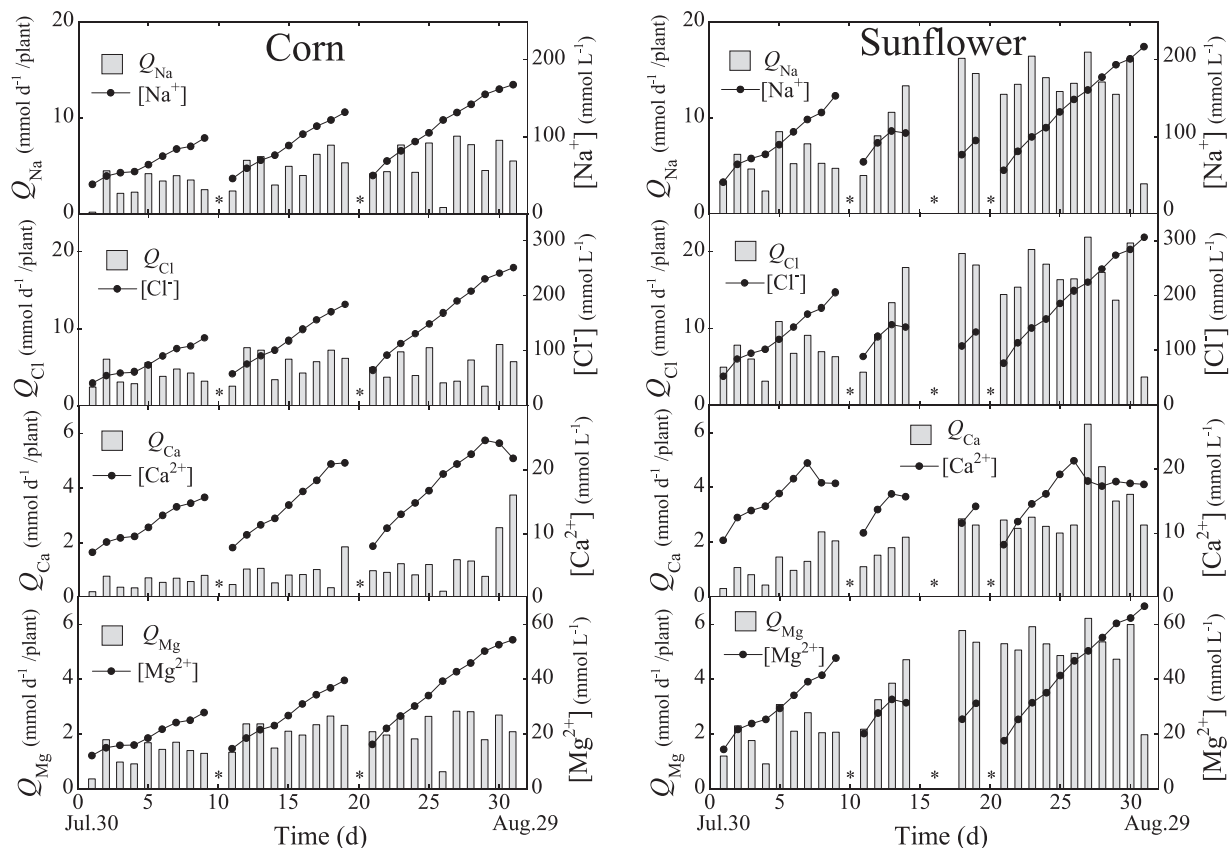

Fig. 3 Time courses of daily integrated rates of root ion absorption $\left(Q_{\mathrm{Na}}, Q_{\mathrm{Cl}}, Q_{\mathrm{Ca}}\right.$ and $\left.Q_{\mathrm{Mg}}\right)$ and ion concentrations in the root zone solution $\left(\left[\mathrm{Na}^{+}\right],\left[\mathrm{Cl}^{-}\right],\left[\mathrm{Ca}^{2+}\right]\right.$ and $\left.\left[\mathrm{Mg}^{2+}\right]\right)$ for the respective ions of $\mathrm{Na}^{+}, \mathrm{Cl}^{-}$, $\mathrm{Ca}^{2+}$ and $\mathrm{Mg}^{2+}$ in corn and sunflower plants growing under the salinized condition. (*, not measured)

compared with corn plants, but the fluctuation of $Q_{\mathrm{M}}$ did not necessarily appeared in parallel with that of $T r$. Furthermore, in the respective plants, $Q_{\mathrm{Na}}$ and $Q_{\mathrm{Cl}}$ under the extremely high $\left[\mathrm{Na}^{+}\right]$and $\left[\mathrm{Cl}^{-}\right]$condition were significantly high as compared with $Q_{\mathrm{Ca}}$ and $Q_{\mathrm{Mg}}$. From these results, it can be considered that $Q_{\mathrm{M}}$ can be affected by both of $\operatorname{Tr}$ and $[\mathrm{M}]$ with an interrelated manner.

Figure 4 shows distributions of $Q_{\mathrm{Na}}$ on $\left[\mathrm{Na}^{+}\right]$(A) and on $\left[\mathrm{Na}^{+}\right] \cdot \operatorname{Tr}(\mathrm{B})$ in corn plants growing under the salinized condition, where the regression curves on the basis of the concentrationdependent model of Eq.(1) and the transpiration-integrated model of Eq.(2) are indicated. The concentration-dependent model represented dependency of $Q_{\mathrm{Na}}$ on $\left[\mathrm{Na}^{+}\right]$with a coefficient of determination $\left(\mathrm{R}^{2}\right)$ of 0.50 , but the transpiration-integrated model represented $Q_{\mathrm{Na}}$ with a coefficient of determination $\left(\mathrm{R}^{2}\right)$ of 0.71 explaining both effects of $\left[\mathrm{Na}^{+}\right]$and $T r$. This suggests that the transpiration-integrated model can represent root ion absorption rate more reliably and more explanatorily than the concentration-dependent model.

Figure 5 shows relationships of $Q_{\mathrm{M}}$ with $[\mathrm{M}] \cdot \operatorname{Tr}$ for the respective ions of $\mathrm{Na}^{+}, \mathrm{Cl}^{-}, \mathrm{Ca}^{2+}$ and $\mathrm{Mg}^{2+}$ in corn and sunflower plants growing under the salinized condition, where the regression curves on the basis of the transpiration-integrated model are indicated. $Q_{\mathrm{M}}$ dependency on $[\mathrm{M}] \cdot T r$ can be reliably represented by the transpiration-integrated model with reasonable identification of the model parameters of $Q_{\max }$ and $K_{\mathrm{M}}{ }^{\prime}$ for each ion species and for each plant species as listed in Table 1. The model parameters of $Q_{\max }$ and $K_{\mathrm{M}}{ }^{\prime}$ can be considered to represent the specificity of root ion absorption for respective plant species and ion species. $Q_{\max }$ can indicate the potential power of root ion absorption under the higher rates of the ion mass flow $([\mathrm{M}] \cdot T r)$ to root cell membranes. On the other hand, $K_{\mathrm{M}}{ }^{\prime}$ can be considered to reflect the affinity of the ion-specific transport proteins to the ion species, and the lower values of $K_{\mathrm{M}}{ }^{\prime}$ indicate the higher affinity under the lower rates of the ion mass flow. $Q_{\max }$ for each ion was significantly higher in sunflower plants than in corn plants, while $K_{\mathrm{M}}{ }^{\prime}$ for each ion was significantly lower in corn plants than in sunflower plants. 


\section{R. NOMIYAMA ET AL.}

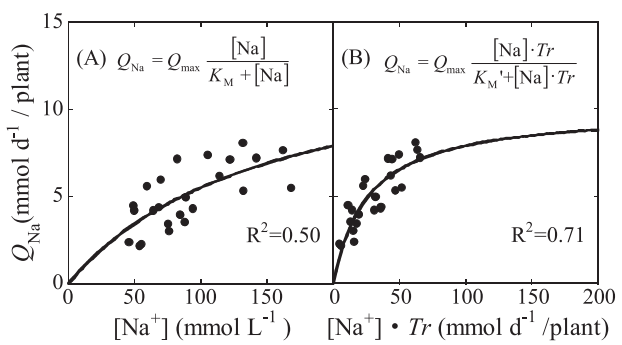

Fig. 4 Distributions of $Q_{\mathrm{Na}}$ on $\left[\mathrm{Na}^{+}\right]$(A) and on $\left[\mathrm{Na}^{+}\right] \cdot \operatorname{Tr}(\mathrm{B})$ in corn plants growing under the salinized condition: Solid curves indicate the regression curves on the basis of the concentration-dependent model (A) and the transpiration-integrated model (B).
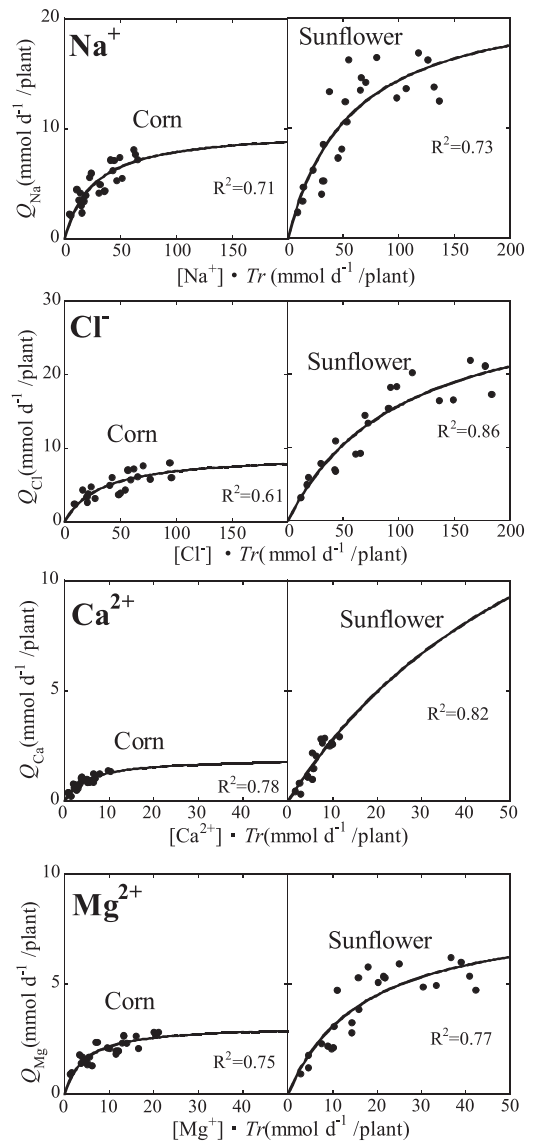

Fig. 5 Relationships of $Q_{\mathrm{M}}$ with $[\mathrm{M}] \cdot \operatorname{Tr}$ for the respective ions of $\mathrm{Na}^{+}, \mathrm{Cl}^{-}, \mathrm{Ca}^{2+}$ and $\mathrm{Mg}^{2+}$ in corn and sunflower plants growing under the salinized condition: Solid curves indicate the regression curves on the basis of the transpiration-integrated model.

This suggests that sunflower plants have the higher absorbing power for each of $\mathrm{Na}^{+}, \mathrm{Cl}^{-}, \mathrm{Ca}^{2+}$ and $\mathrm{Mg}^{2+}$ under the higher rates of the ion mass flow to root cell membranes and that corn plants have the higher affinity of the ion-specific transport proteins to each ion under the lower rates of the ion mass flow.

Normalizing the root ion absorption rate $\left(Q_{\mathrm{M}}\right)$ with the potential absorbing power $\left(Q_{\max }\right)$ 


\section{KINETIC MODEL OF ROOT SALT ABSORPTION}

identified for respective plant species and ion species, $Q_{\mathrm{M}} / Q_{\max }$ varies within a range of 0 to 1 and can be expressed by the normalized transpiration-integrated model as

$$
Q_{\mathrm{M}} / Q_{\max }=\frac{[\mathrm{M}] \cdot \operatorname{Tr} / Q_{\max }}{K_{\mathrm{M}}{ }^{\prime} / Q_{\max }+[\mathrm{M}] \cdot \operatorname{Tr} / Q_{\max }}
$$

Figure 6 shows relationship between $Q_{\mathrm{M}} / Q_{\max }$ and [M] $\operatorname{Tr} / Q_{\max }$ in both of corn and sunflower plants for the respective ions of $\mathrm{Na}^{+}, \mathrm{Cl}^{-}, \mathrm{Ca}^{2+}$ and $\mathrm{Mg}^{2+}$, where the regression curves based on the normalized transpiration-integrated model of Eq.(3) are indicated for each plant species. The relationship identified on the basis of Eq. (3) in each ion species was expressed by almost the same curve for both of corn and sunflower plants. This suggests that the model parameter of $Q_{\max }$ (i.e. the potential absorbing power) can be an important explanatory parameter to represent the specificity of plant species in root ion absorption. Furthermore, Fig. 7 shows relationship between $Q_{\mathrm{M}} / Q_{\max }$ and $[\mathrm{M}] \cdot \operatorname{Tr} / Q_{\max }$ for all the ions of $\mathrm{Na}^{+}, \mathrm{Cl}^{-}, \mathrm{Ca}^{2+}$ and $\mathrm{Mg}^{2+}$ in the respective plants of corn and sunflower, where the regression curves based on the normalized transpiration-integrated model of Eq. (3) are indicated for each ion species. The relationships identified on the basis of Eq. (3) in each plant species were expressed by the similar regression curves for all the ion species. This suggests that the specificity of ion species in root ion absorption can be also represented by the model parameter of $Q_{\max }$.

Table 1 Parameters of $Q_{\max }$ and $K_{M}$ involved in the transpiration-integrated model for the respective ions of $\mathrm{Na}^{+}, \mathrm{Cl}^{-}, \mathrm{Ca}^{2+}$ and $\mathrm{Mg}^{2+}$ in corn and sunflower plants growing under the salinized condition.

\begin{tabular}{cccccc}
\hline species & model parameter & $\mathrm{Na}^{+}$ & $\mathrm{Cl}^{-}$ & $\mathrm{Ca}^{2+}$ & $\mathrm{Mg}^{2+}$ \\
\hline \multirow{2}{*}{ corn } & $Q_{\max }\left(\mathrm{mmol} \mathrm{d}{ }^{-1} /\right.$ plant $)$ & 10.0 & 9.2 & 1.9 & 3.2 \\
& $K_{\mathrm{M}}{ }^{\prime}\left(\mathrm{mmol} \mathrm{d}{ }^{-1} /\right.$ plant $)$ & 26.3 & 32.9 & 5.1 & 4.5 \\
\hline \multirow{2}{*}{ sunflower } & $Q_{\max }\left(\mathrm{mmol} \mathrm{d}{ }^{-1} / \mathrm{plant}\right)$ & 22.4 & 32.0 & 22.1 & 8.4 \\
& $K_{\mathrm{M}}{ }^{\prime}\left(\mathrm{mmol} \mathrm{d}{ }^{-1} /\right.$ plant $)$ & 56.2 & 103.0 & 69.2 & 17.4 \\
\hline
\end{tabular}
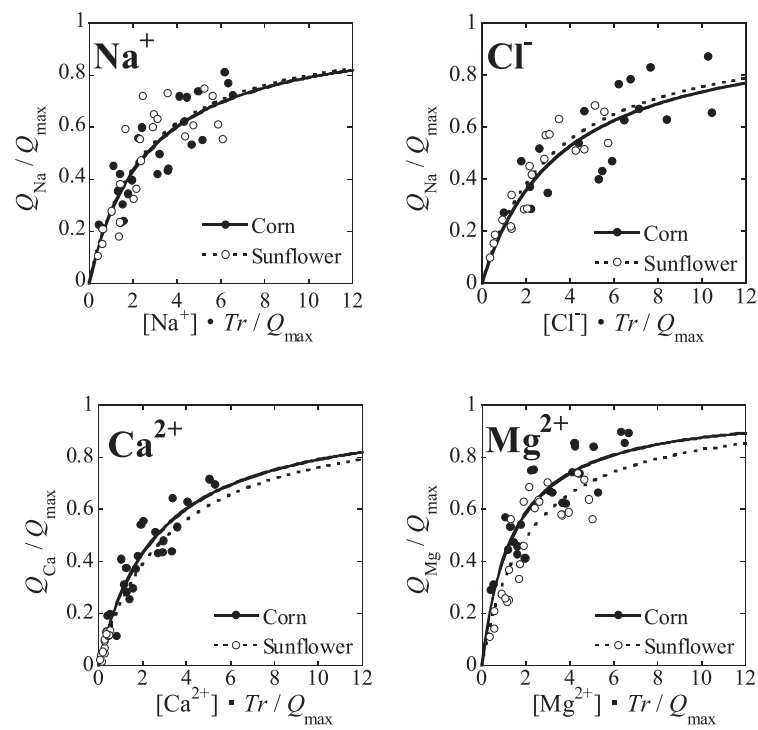

Fig. 6 The relationship of $Q_{\mathrm{M}} / Q_{\max }$ with [M] $\operatorname{Tr} / Q_{\max }$ in both of corn and sunflower plants for the respective ions of $\mathrm{Na}^{+}, \mathrm{Cl}^{-}, \mathrm{Ca}^{2+}$ and $\mathrm{Mg}^{2+}$. The regression curves based on the transpiration-integrated model normalized by $Q_{\max }$ are indicated for each plant species: Solid curves, corn plants; broken curves, sunflower plants. 


\section{R. NOMIYAMA ET AL.}
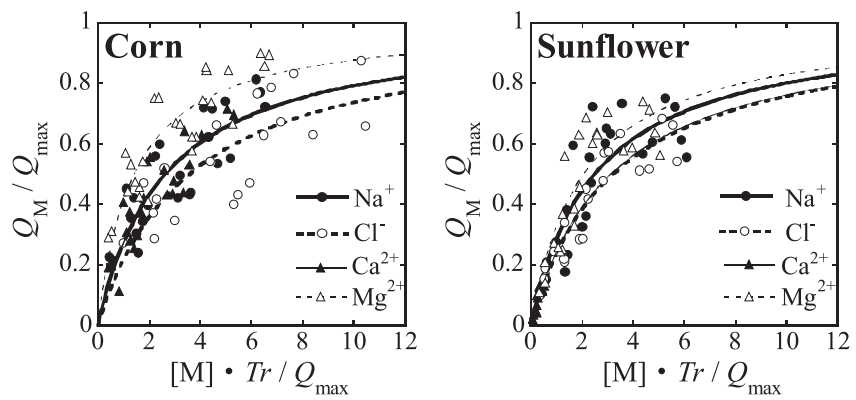

Fig. 7 The relationship of $Q_{\mathrm{M}} / Q_{\max }$ with $[\mathrm{M}] \cdot \mathrm{Tr} / Q_{\max }$ for all the ions of $\mathrm{Na}^{+}, \mathrm{Cl}^{-}, \mathrm{Ca}^{2+}$ and $\mathrm{Mg}^{2+}$ in the respective plants of corn and sunflower. The regression curves based on the transpiration-integrated model normalized by $Q_{\max }$ are indicated for each ion species: Bold solid curves, $\mathrm{Na}^{+}$; bold broken curves, $\mathrm{Cl}^{-}$; thin solid curves, $\mathrm{Ca}^{2+}$; thin broken curves, $\mathrm{Mg}^{2+}$.

Thus, the characteristics of root salt absorption of corn and sunflower plants (the major crops in arid and semi-arid regions) were explained quantitatively by two parameters $\left(Q_{\max }\right.$ and $\left.K_{\mathrm{M}}{ }^{\prime}\right)$ involved in the transpiration-integrated model. In particular, the parameter of $Q_{\max }$, which relates to the potential power of root ion absorption, can be an important explanatory parameter to represent the specificity of plant species and ion species in root ion absorption. In the salinized crop fields, salts containing $\mathrm{Na}^{+}, \mathrm{Cl}^{-}, \mathrm{Ca}^{2+}$ and $\mathrm{Mg}^{2+}$ are highly accumulated in the root zone soil due to the selective ion absorption of crop roots (Kitano et al., 2006), and this salt accumulation varies depending on the specificity of plant species in root absorptive functions (Nomiyama et al., 2012). Therefore, identification of the parameter of $Q_{\max }$ for the major crops can be effective for simulation of salt accumulation in the root zone soil, which is necessary for planning a sustainable crop rotation system to slow down the salinization of crop fields.

This study was supported by the Grant-in-Aid for Scientific Research (No. 23380150 and No. 23405037) from the Japan Society for the Promotion of Science, and supported by Research Institute for East Asia Environments, Kyushu University.

\section{REFERENCES}

Epstein, E., Hagen, C. E. 1952. A kinetic study of the absorption of alkali cations by barley roots. Plant Physiol. 13: 457-474.

FAO 2002. Agricultural drainage water management in arid and semi-arid areas. FAO Irrigation and Drainage Paper 61. Food and Agriculture Organization of the United Nations, Rome, pp 204.

Katou, K., Furumoto, M. 1986a. A mechanism of respiration-dependent water uptake in higher plants. Protoplasma 130: 80-82.

Katou, K., Furumoto, M. 1986b. A mechanism of respiration-dependent water uptake enhanced by auxin. Protoplasma 133: 174-185.

Kitano, M., Yasutake, D., Kobayashi, T., Hidaka, K., Wajima, T., Wang, W., He, W. $2006 . \quad$ Dynamics of water and ion transport driven by corn canopy in the Yellow River basin. Biologia 61(Suppl.19): 275-279.

Nomiyama, R., Ebihara, K., Takata, M., Sakamoto, D., Sago, Y., Yasutake, D., Marui, A., Eguchi, T., Mori, M., Araki, T., Tagawa, K., Cho, H., Wu, Y., Wang, W., Kitano, M. 2012. Root absorptive functions drive salt accumulation in crop fields under desertification II. Effects of different species. Eco-Engineering 24: (in press).

Pitman, M. G. 1977. Ion transport into the xylem. Annu. Rev. Plant Physiol. 28: 71-88.

Sago, Y., Yasutake, D., Hidaka, K. Yasunaga, E., Eguchi, T., Yoshida, S., Kitano, M. 2011a. Kinetics of root ion absorption affected by environmental factors and transpiration II. Environmental effects and a concen- 


\section{KINETIC MODEL OF ROOT SALT ABSORPTION}

tration-dependent model. Environ. Control Biol. 49: 33-40.

Sago, Y., Yasutake, D., Hidaka, K., Yasunaga, E., Eguchi, T., Yoshida, S., Kitano, M. 2011b. Kinetics of root ion absorption affected by environmental factors and transpiration III. A kinetic model integrated with transpiration. Environ. Control Biol. 49: 41-46.

Taiz, L., Zeiger, E. 2002. Plant Physiology, 3rd edition. Sinauer Associates, Sunderland, pp 691.

Taura, T., Iwaikawa, Y., Furumoto, M., Katou, K. 1988. A model for radial water transport across plant roots. Protoplasma 144: 170-179.

Yasutake, D., Hidaka, K., Sago, Y., Araki, T., Kitano, M., Kobayashi, T., Ishikawa, K. 2009a. Absorption and transport of water and ions in corn and sunflower plants grown under saline conditions. J. Agric. Meteorol. 65: 19-26.

Yasutake, D., Araki, T., Wang, W., Kobayashi, T., Cho, H., Mori, M., Kitano, M. 2009b. Analysis of salts transport affected by root absorption capacity in surface-irrigated fields in the upper Yellow River basin. Biologia 64: 570-574.

Yasutake, D., Kitano, M., Yasunaga, T., Wajima, T. M., Affan, F. F., Hamakoga, M., Maki, T. 2004. Dynamic evaluation of uptake of water and mineral nutrients by roots. (in Japanese with English abstract) Eco-Engineering 16: 215-222. 